\title{
THE FISCAL FRAMEWORK AND URBAN INFRASTRUCTURE FINANCE IN CHINA
}

\author{
By Ming Su and Quanhou Zhao ${ }^{1}$
}

World Bank Policy Research Working Paper 4051, November 2006

The Policy Research Working Paper Series disseminates the findings of work in progress to encourage the exchange of ideas about development issues. An objective of the series is to get the findings out quickly, even if the presentations are less than fully polished. The papers carry the names of the authors and should be cited accordingly. The findings, interpretations, and conclusions expressed in this paper are entirely those of the authors. They do not necessarily represent the view of the World Bank, its Executive Directors, or the countries they represent. Policy Research Working Papers are available online at http://econ.worldbank.org.

\footnotetext{
${ }^{1}$ The Research Institute for Fiscal Science, MOF. P.R.China
} 
Since its economic reform and opening to the outside, China has experienced impressive economic development. Between 1978 and 2004, China’s annual GDP growth rate averaged 9.4\%, far above the world average of 2.8\%. Economic growth has been accompanied by rapid urbanization. In 1978, only $17.9 \%$ of China’s population lived in urban areas; by 2003 , the urbanization rate was $40.5 \%$.

Although the urban infrastructure capital stock also has expanded swiftly—probably faster than anywhere else in the world--it has not kept pace with the rate of industrialization and urbanization. Until recently, China’s urban infrastructure financing was heavily dependent on the fiscal budget. Fiscal capacity constraints, especially in the lower levels of government, have forced governmental authorities to make greater use of borrowing, introducing a new degree of risk into intergovernmental finance, but urban infrastructure construction continues to lag behind the rate that many experts believe is required to sustain China's extraordinary economic growth.

To analyze the impact of the fiscal framework on urban infrastructure financing, we need first to understand the outline of China's fiscal system. This chapter summarizes the principal reforms that have led to today's fiscal framework, then considers the current situation and future options for urban infrastructure finance. 


\section{PART I}

\section{CHINA’S FISCAL SYSTEM AND THE CHANGE OF FISCAL}

\section{POLICY}

China's market-oriented economic reforms started in 1978. The nation gradually phased out the planned economic system, and shifted economic power to decentralized levels of government and companies. Reform of the fiscal system thus underlies national economic reform.

\section{The pre-reform fiscal pattern}

The pre-reform fiscal regime of China was adapted to the highly concentrated planning economy. Not only did the government do everything, but sub-national governments were totally dependent on the central government. It was a typical regulated fiscal regime, in which all taxes and profits were remitted to the center and then transferred back to the provinces and from there to the local level. ${ }^{2}$ Policymakers in the central government decided what type of revenues should be collected and how these revenues were to be reallocated for national and sub-national public goods.

The pre-reform fiscal regime had the merit of generating broadly equal fiscal capacity among different regions. However, it provided no incentives for sub-national

\footnotetext{
${ }^{2}$ In China, the term "local” is commonly used to describe all sub-national units of government. In this chapter, "local” refers to sub-provincial units, including municipalities, townships, and counties.
} 
governments to promote economic growth or collect budgetary revenues.

The Fiscal Contracting System: 1980-1993

China began its fiscal decentralization reform in earnest in 1980, with the goal of giving sub national governments more and more power to finance their own needs subject to a budget constraint. The initial strategy involved a variety of contracting methods, whose basic spirit was to apportion revenues and expenditures between the central and local authorities while holding the latter responsible for their own profits and losses. The fiscal contracting system gradually evolved into 6 contracting categories by 1988 — viz. contract sharing of incremental revenues, proportional sharing of base revenue, proportional base sharing plus incremental sharing, contractually designated incremental remittance amounts, fixed remittance, and fixed central subsidy.

The fiscal contracting system gave sub-national governments a certain space to decide their own affairs (a kind of fiscal deregulation), encouraging them to develop the regional economy and collect revenues. From a national perspective, the system had two principal drawbacks. First, it caused the central government share of fiscal revenues to decline steeply. This phenomenon was due in part to the fact that provincial and municipal governments "gamed” the system by producing just enough on-budget shared revenue to satisfy their contract obligations, while shifting 
further revenue generation to off-budget and other revenue sources that did not have to be shared. Central government revenue as a percentage of total fiscal revenue fell from $34.8 \%$ in 1985 to $22 \%$ in 1992 . Second, the different contracting methods were complicated and inequitable, enlarging the fiscal differentials between regions. Rich provinces (such as Guangdong) had more bargaining power, and benefited from more favorable fiscal contracts. In addition, under the contracting system, the central government fell into an inefficient track of constantly bargaining with sub-national governments over revenue-sharing terms.

\section{“Tax assignment system” reform of 1994}

In 1994, China undertook a fundamental intergovernmental fiscal reform called the tax assignment system reform. The objectives of the reform package were to: (1) simplify and rationalize the tax structure by reducing tax categories and tax rates thereby unifying the tax burden on taxpayers, and cutting down tax exemptions;

(2) raise the overall fiscal revenue-to-GDP ratio; (3) raise the central government's share of total fiscal revenues; and (4) put central-local revenue sharing on a more transparent, objective basis by shifting from revenue-sharing contract negotiations to a tax and revenue assignment system. 
Expenditure assignments between the central and sub-national governments

The 1994 reforms concentrated solely on the revenue side of public budgets. No expenditure assignments were made. In fact, there still is no legislation in China that codifies the expenditure responsibilities of different tiers of government, either between the Central and Provincial level, or between Provinces and the Local level. Leaving intergovernmental expenditure responsibilities undefined has given upper tier governments more flexibility of offloading responsibilities to lower tiers, without compensatory transfers of revenue or fiscal autonomy.

Table 1 identifies the key expenditure functions commonly understood to be sub-national functions. The list is extensive and costly. Most of the service delivery functions, along with the corresponding investment in urban infrastructure, are the responsibilities of local governments. The local level is also responsible for economic development and economic planning — which involves pro-active direction of the local enterprise sector. Local governments in China also have much greater responsibility for poverty alleviation and social protection of displaced workers than is true in the West, where these functions are assumed primarily by central government. 
Table 1: Sub-National Expenditure Responsibilities

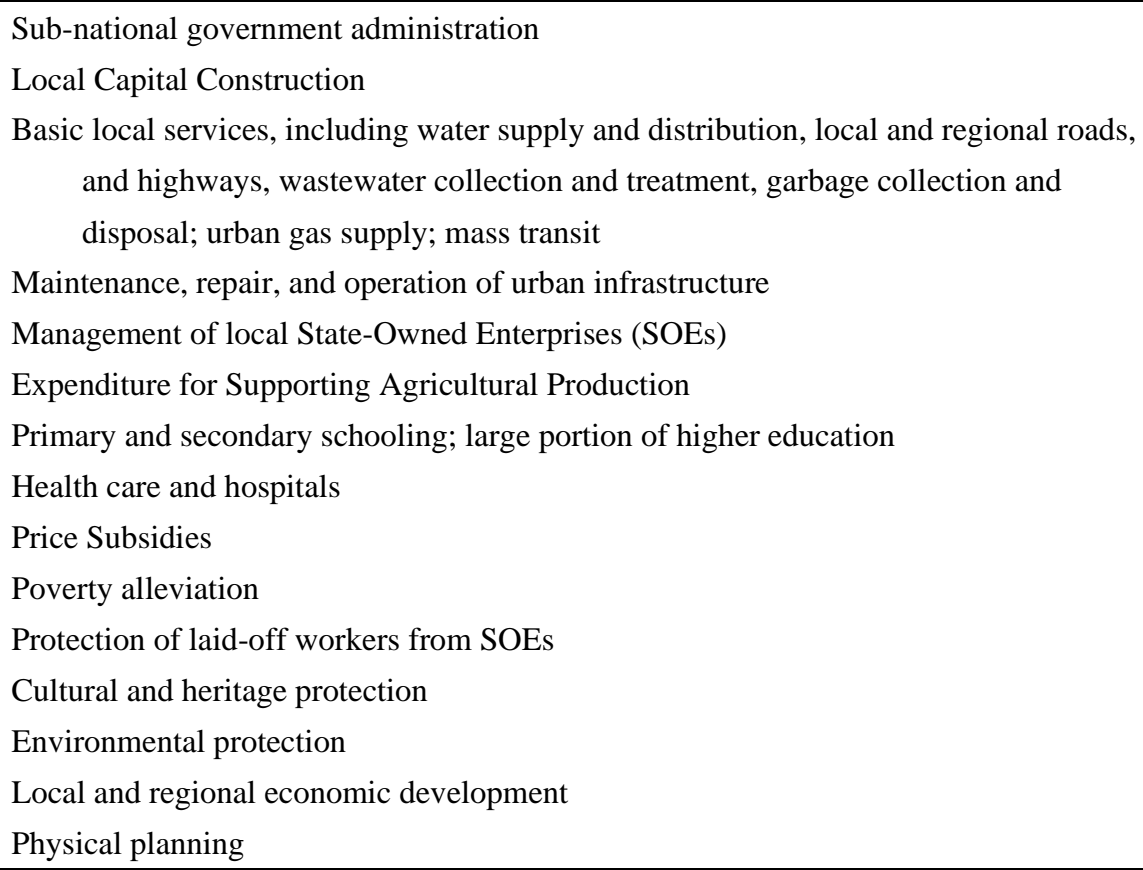

Source : Author

\section{Revenue assignment:}

The principle of revenue assignment between the central and sub-national governments is that taxes concerning national interest or macroeconomic adjustment belong to the central government and those with regard to local economic development are under the jurisdiction of sub-national governments. Table 2 shows the specific situation after the 1994 reform. 
Table 2: Revenue Assignment between Central and Sub-National Governments, 1994

\begin{tabular}{|c|c|}
\hline $\begin{array}{l}\text { The central } \\
\text { Revenues }\end{array}$ & $\begin{array}{l}\text { Import Tariffs } \\
\text { Consumption Taxes } \\
\text { Income Taxes and Profits of SOEs under the jurisdiction of the central government } \\
\text { Import-related consumption taxes and VATs } \\
\text { Taxes imposed on banks, nonbank financial institutions and insurance companies } \\
\text { (include business taxes, income taxes, and Urban Maintenance and Development } \\
\text { Tax) } \\
\text { Taxes on railroads. }\end{array}$ \\
\hline $\begin{array}{l}\text { Sub-national } \\
\text { Revenues }\end{array}$ & $\begin{array}{l}\text { Business Tax (excluding banks, nonbank financial institutions and insurance } \\
\text { companies, and railroads) } \\
\text { Company Income Tax (excluding local banks, foreign banks, and nonbank financial } \\
\text { companies) } \\
\text { Profits of locally owned SOEs } \\
\text { Personal Income Tax } \\
\text { Urban Land Use Tax } \\
\text { Urban Maintenance and Development Tax (excluding banks, nonblank financial } \\
\text { institutions and insurance companies, and railroads) } \\
\text { Fixed Assets Capital Gains Tax } \\
\text { House property taxes } \\
\text { Stamp taxes } \\
\text { Agriculture and Related Taxes } \\
\text { Tax on Contracts } \\
\text { Land value increment taxes }\end{array}$ \\
\hline $\begin{array}{l}\text { Shared } \\
\text { Revenues }\end{array}$ & $\begin{array}{l}\text { Value Added Taxes (the central 75\%, sub-national governments 25\%) } \\
\text { Stamp Taxes on Security Exchange (50\%-50\%) } \\
\text { Resource Taxes }\end{array}$ \\
\hline
\end{tabular}

Source : Author

A distinctive characteristic of this revenue assignment was that, while it initially boosted significantly the central government's share of total revenue (see below), it assigned to sub-national governments all or part of what turned out to be the fastest-growing major revenue sources-100\% of the personal income tax, most of the company income tax, and 25\% of VAT. 


\section{Central-to-sub-national transfer system}

The intergovernmental fiscal reform also defined a new intergovernmental transfer system. What is called "tax rebating” from the central to sub-national governments is actually a kind of transfer payment, a grant paid to provinces in relation to the growth in certain tax revenues since the last pre-reform year, 1993. Revenue increments from the consumption tax and value-added tax collected in a province are received by central government, then up to $30 \%$ is "rebated" to the province in the form of a tax-related return grant.

A second type of transfer from the center was introduced. This is a formula-based grant based on the gap between a province’s 'standardized' fiscal expenditure and its ‘standardized’ fiscal revenue. All central transfers are made to provincial governments. The provinces then transfer revenues to the local level, generally following grant arrangements modeled after the central-to-provincial design.

\section{General tax reform}

These changes in the intergovernmental fiscal system were made within the context of a general overhaul of the tax system. The most dramatic changes were establishment of a VAT-dominated turnover tax system, and unification of the various 
elements of domestic income tax. The tax changes had the objective of increasing total fiscal revenues, assuring future growth of fiscal revenues in line with economic growth, and increasing the central government share of fiscal revenues. To ensure effective collection of the central government's portion of revenues, the central and sub-national governmental tax collection bureaus were separated. The national tax collection bureau now is in charge of collecting revenues from tax sources that are the exclusive domain of the central government, as well as revenues from shared taxes, while the local tax bureaus are in charge of collecting sub-national tax revenues.

\section{Changes in revenue rules after 1994}

After 1994, further changes in the intergovernmental revenue system have been made, but more gradually. Most of the changes have taken the form of increasing central government's portion of shared revenues, increasing tax rates on centrally collected taxes, or eliminating various sub-national taxes and fees.

First, in 1997, the sharing proportion of the revenue from Stamp Taxes on Security Exchange between the central and local governments was changed from $50 \%-50 \%$ to $88 \%-12 \%$. Later, the sharing ratio was again adjusted, moving gradually from $88 \%-12 \%$ to $97 \%-3 \%$.

Second, the company tax rate on the finance and insurance industry was 
increased from $5 \%$ to $8 \%$, with all of the increase going to the central government. (The tax rate was reduced to the original level (5\%) between 2001 and 2003, because of the economic slowdown.)

Third, income tax revenue-sharing was introduced in 2002. Except for some special industries and companies (such as banks, China Gas Company, and China Oil and Chemical Company), the tax-sharing arrangement provided that central and sub-national governments would in the future share the combined revenues of company (business) income taxes and personal income taxes. The local governments would keep the income tax revenues collected in 2001 as a base, but increases would be shared between central and local governments. In 2002, the central government sharing rate was introduced at 50\%. From 2003 to now, the central government's sharing rate has been $60 \%$. This change has had the effect of converting the fastest-growing significant sources of tax revenue—-the company and personal income taxes—from sub-national taxes to shared taxes, the majority of whose revenue goes to the central government.

Fourth, starting from 2004, the government announced that China will progressively abolish the agriculture tax system over the next 5 years in order to lighten the farmers' tax burden. Several provinces have already totally eliminated the agricultural tax, while other provinces have lowered the agriculture tax rate from $3 \%$ to $1 \%$. To partially compensate for the lost sub-national revenue, the central 
government increased special transfer payments by RMB 9.1 billion as budget-gap coverage.

Finally, from 1997 until now, the central government has issued a series of documents to cancel, regulate, or limit the fees and user charges that can be collected at the sub-national (mostly urban) level.

Generally speaking, the tax assignment reform established a new fiscal framework for China. It set up a better-defined and rational arrangement of inter-governmental financing. The new system enables all levels of government to have their own exclusive revenue sources, clarifying the boundaries of revenue allocation between different levels. A formula-based transfer system was introduced. As was intended, the tax assignment system gives sub-national governments more power to develop their economies, and to collect their own taxes.

The reforms carried out since 1994, however, have caused sub national governments a great deal of fiscal difficulty. They have re-centralized fiscal revenues without cutting back on sub-national governments’ expenditure responsibilities. 


\section{THE REVENUE IMPACT OF FISCAL REFORM}

The 1994 fiscal reform had the desired effect of accelerating fiscal revenue collection. Before 1994, total fiscal revenue was growing between RMB 20 and 30 billion annually. After 1994, the annual fiscal revenue growth increased to more than RMB 150 billion on average. Figure 1 shows the trend of China’s fiscal revenue.

Figure 1: China's fiscal revenue and its structure

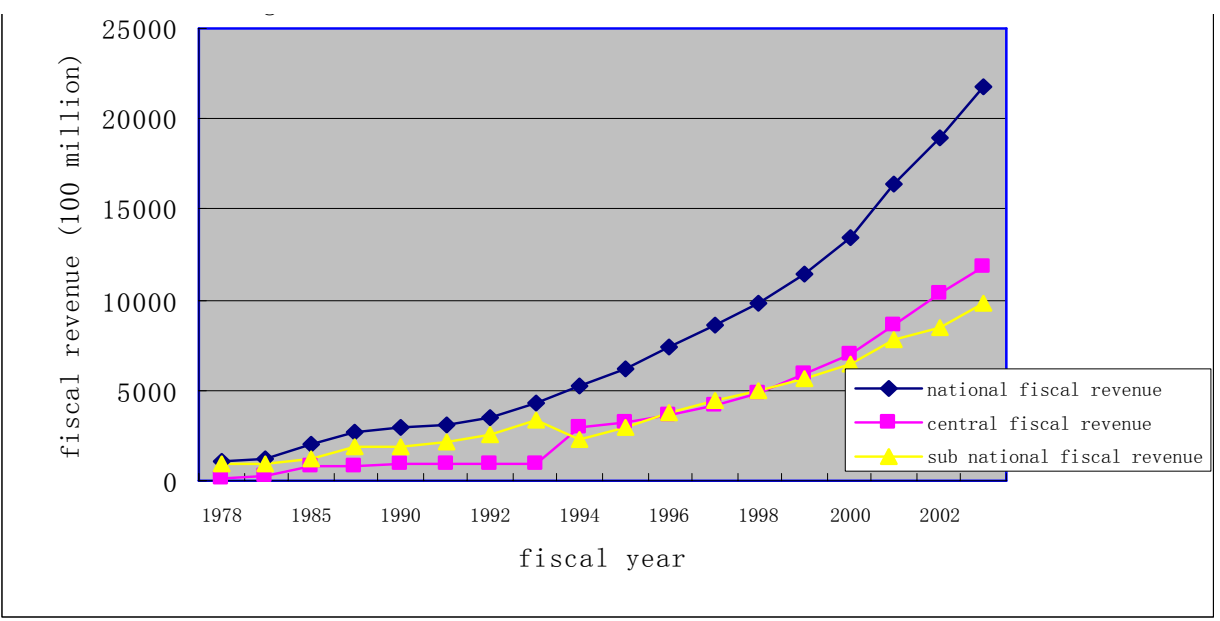

Source : Authors calculations

The 1994 reform also had the intended effect of shifting fiscal revenues from sub-national governments to the central government. This impact can be seen clearly in Figure 1, where central revenues jump ahead of sub-national revenues for the first time in 1994. Subsequent changes in revenue-sharing rules have assured that central-government fiscal revenues continue to grow faster than sub-national fiscal revenues. Under the fiscal contracting system, the sub-national share of total fiscal revenue was very high, reaching a peak of $78.9 \%$ in $1993 . \quad$ After 1994, due to the newly introduced tax assignment system, and subsequent increases in the central 
portion of shared taxes, the sub-national governmental revenue share steadily declined from $78 \%$ in 1993 to $45 \%$ in 2002 . The tax assignment system has cut sharply into sub-national governments' own revenues and their share of fiscal revenue distribution.

On the expenditure side of budgets, however, the share of sub-national government spending in total fiscal expenditure has kept stable, at roughly $70 \%$ (see Figure 2).

Figure 2: National fiscal expenditure and its structure

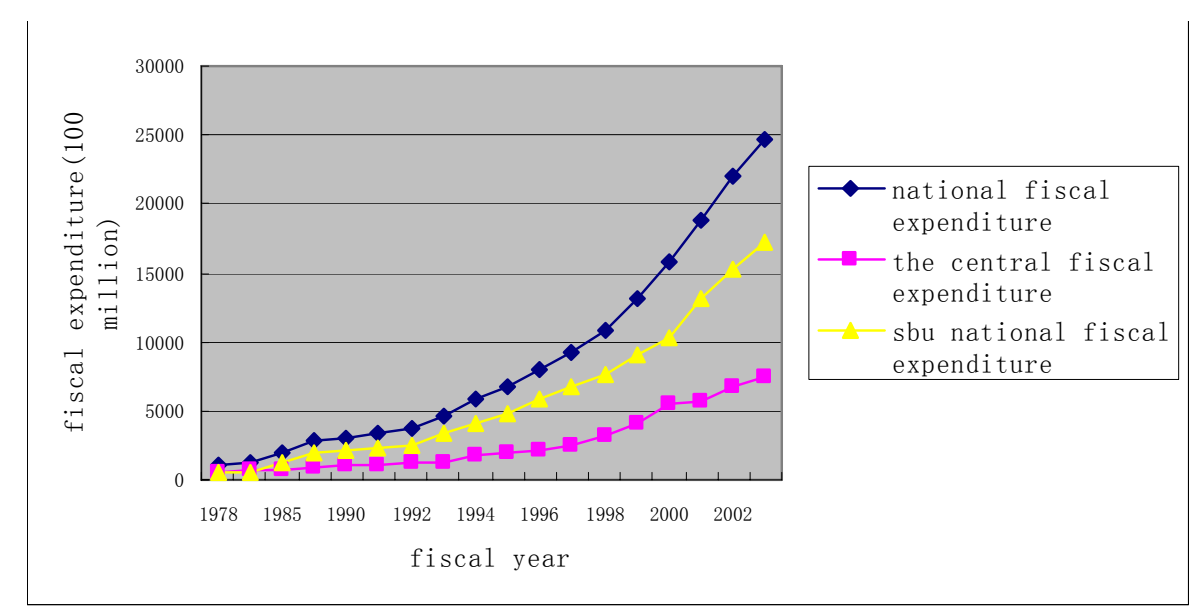

Source : Authors calculations

The widening fiscal gap between sub-national expenditure and sub-national fiscal revenue is shown dramatically in Figure 3. As a result of these trends, sub-national governments have grown more and more fiscally dependent on the central government. The tax rebating system has become a type of universal grant, which all sub-national governments need to receive. At the same time, regional disparities in income, fiscal revenue, and self-financing capacity have grown. Figure 4 shows that the sub-national 'self-support' rate ranges from almost $90 \%$ in Beijing to 
less than 40\% in Qinghai (Tibet may be viewed as an exceptional case.)

Figure 3: Sub-National Fiscal Revenue and Expenditure

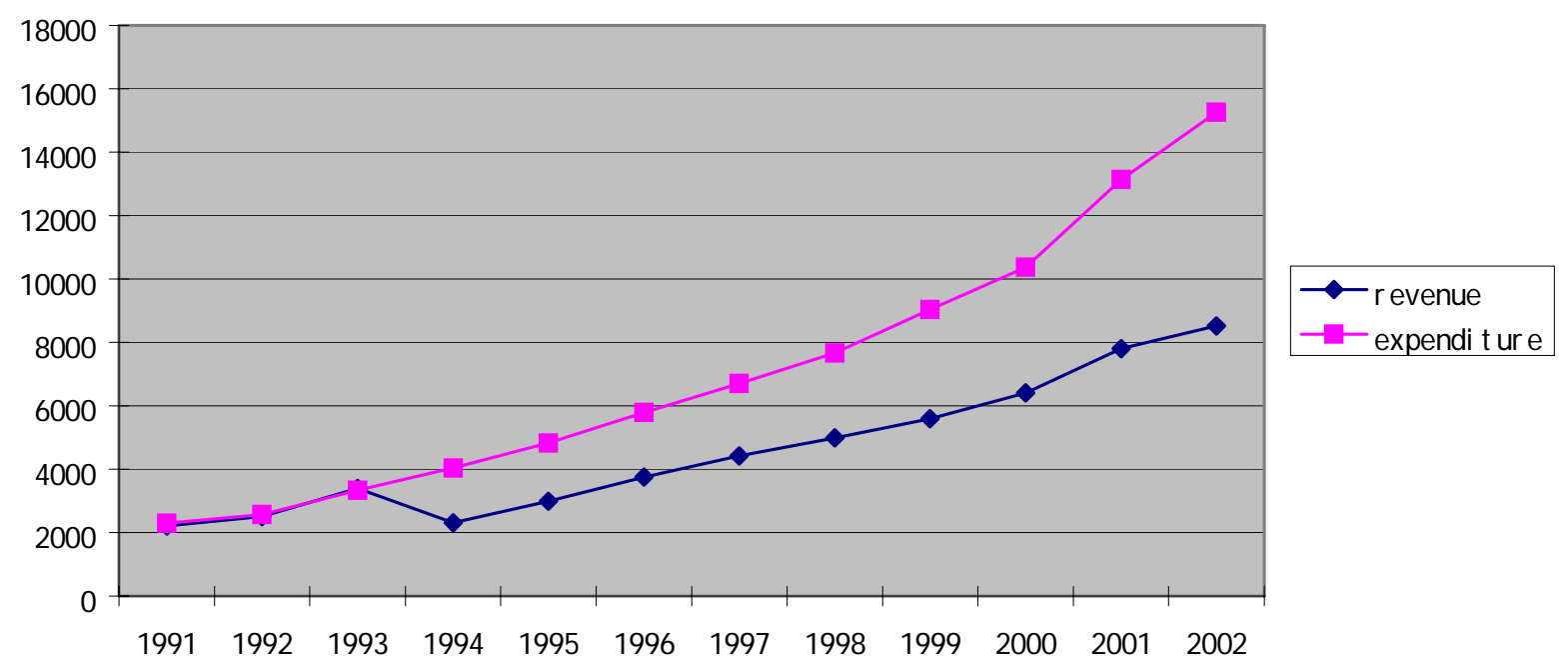

Source : Authors calculations

Figure.4: The sub-national governments’ self-support rate （\%)

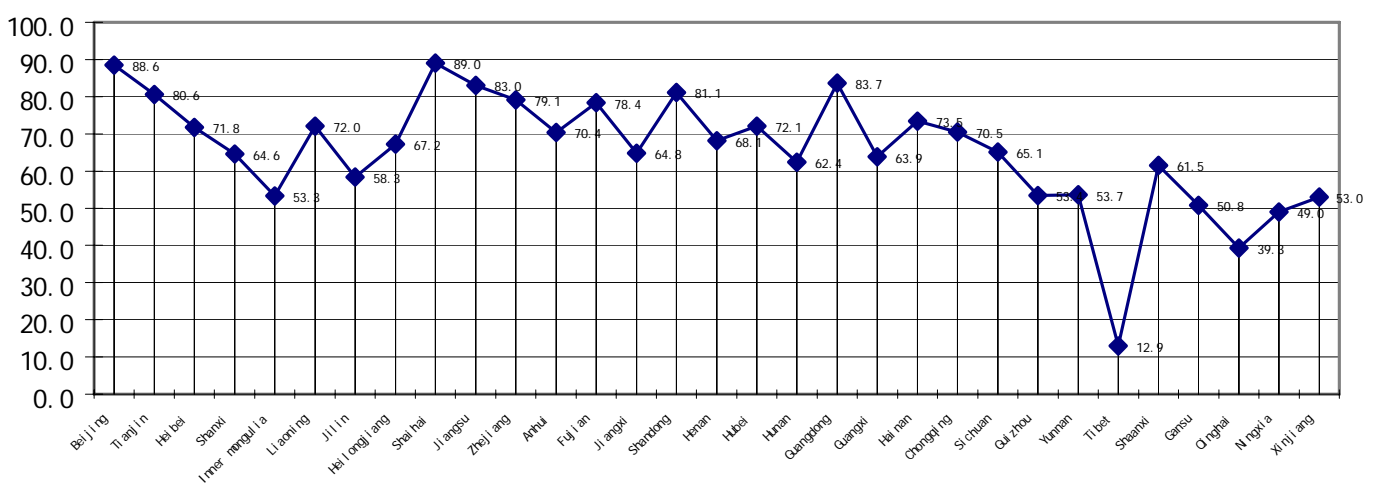

Source : Authors calculations

Note: The fiscal self-support rate is the share of own-source revenue in total revenue. 


\section{THE TRANSFER SYSTEM FROM CENTRAL TO SUB NATIONAL}

\section{LEVEL}

Under the present fiscal system in China, transfer payments from central to sub-national governments are important, but quantitatively they do not offset the widening disparity in own-source revenue collection and qualitatively they do not fully incorporate the new norm of a formula-based standardized system. Reforms in the transfer system have been hampered by the political/economic power of high-growth regions. The largest part of intergovernmental transfers is still based on incremental revenue sharing (tax rebating) relative to 1993 base-year receipts.

\section{The tax rebating system}

After the 1994 reform, in order to compensate sub-national governments' revenue losses, the central government introduced the tax rebating system described above. The tax revenue rebating scale is decided directly by: first, upwardly transferring the amount that was transferred by sub-national governments to the center in 1993; second, the overall incremental revenue growth of VAT and Consumption tax revenue is computed; third, it is determined whether or not revenue collected within a particular province is at least as large as in 1993. Provinces that meet this hurdle receive tax rebates. The rebate system is scaled so as to enable the richer provinces to get more tax rebating, expanding fiscal disparities among regions. 


\section{The "standardized” fiscal transfer system:}

In 1995, a new "standardized” transfer system was introduced in addition to the above-described rebate system. Based on formula, the new system aimed to establish an objective, normative transfer mechanism. The amount of funds disbursed under the standardized transfer system has grown continually, from RMB 2.1 billion in 1995 to 74.5 billion in 2004, but the transfer amount under this method is still small compared to the magnitude of tax rebating.

Up to now, the formula for the standardized fiscal transfer has been very simple and unstable. For example, the formula in 2002 was: The volume of transfer payment of province $\mathrm{N}=$ (the $\mathrm{N}$ regional standardized expenditure - the $\mathrm{N}$ regional standardized revenue) $\times$ the transfer coefficient of province N. Only when the standardized expenditure is larger than the standardized revenue could the province $\mathrm{N}$ obtain fiscal aid (net transfer payment).

Standardized revenues are calculated according to the regional tax base and the tax rates for sub-national and shared taxes. Since all tax rates are set at the national level, differences in standardized revenue reflect differences in tax base capacity. Standardized expenditure is mainly the sum of a province's expenditures for government employees, education, and administration, all calculated at “standardized” rates (e.g., a standard number of public employees per 1000 
population.) The transfer coefficient for a particular province is calculated taking account of the regional standardized expenditure, standardized revenue, the situation of fiscal deficit, and the overall pool available for transfer payment. So the transfer coefficient is flexible year by year. Provinces cannot accurately project their transfer receipts in advance, nor can they calculate the impact on transfers of the budget adjustments they make.

Municipalities and other sub-provincial governments are subject to the same type of transfer formula at the provincial level, and the same uncertainty surrounding transfer amount.

\section{Earmarked grants}

Aside from the two transfer systems, there still are earmarked grants.

In 1999, a transfer for income distribution adjustment was introduced when the central government decided to increase the middle and the lower classes' income. The transfer was earmarked for income distribution and excluded some rich areas, such as Beijing, Shanghai, Jiangsu, Zhejiang, Guangdong, Fujian, and Shandong. The transfer amount in 1999 was RMB 10.8 billion, doubled in 2000, and reached 40.3 billions in 2001.

Further earmarking grants were introduced in conjunction with China's 
western economic development program. For example, the transfer payment earmarked for minority areas was established in 2000 in order to support the minority areas’ economic development. Similar grants are now being earmarked for re-development of China's rustbelt region in the Northeast.

Table 3 summarizes the overall transfer payment structure in China in recent years.

Table 3: 1995 - 2004 Transfer payment from the central to sub national level

\begin{tabular}{|c|c|c|c|c|c|c|c|c|c|c|}
\hline Fiscal year & 1995 & 1996 & 1997 & 1998 & 1999 & 2000 & 2001 & 2002 & 2003 & 2004 \\
\hline Total & 2449 & 2655 & 2784 & 3228 & 3931 & 4588 & 5893 & 7348 & 8656 & 10177 \\
\hline Tax rebating and & & & & & & & & & & \\
\hline fixed subsidy amounts & 1982 & 2060 & 2124 & 2196 & 2234 & 2326 & 2431 & 3328 & 4196 & 4335 \\
\hline Transfer payments for & & & & & & & & & & \\
\hline fiscal capacity & 91 & 107 & 143 & 155 & 336 & 506 & 1108 & 1586 & 1884 & 2618 \\
\hline Of which:: & & & & & & & & & & \\
\hline Standardized fiscal transfer & 20 & 35 & 50 & 61 & 75 & 85 & 138 & 279 & 380 & 745 \\
\hline Earmarked for minority areas. & & & & & & 25 & 35 & 39 & 55 & 76 \\
\hline Income distribution adjustment. & & & & & 108 & 217 & 631 & 817 & 901 & 993 \\
\hline $\begin{array}{l}\text { Grant for "fees and } \\
\text { tax reform" in rural } \\
\text { area }\end{array}$ & & & & & & & 80 & 245 & 305 & 307 \\
\hline $\begin{array}{l}\text { Grant for abolition } \\
\text { of agriculture tax }\end{array}$ & & & & & & & & & & 217 \\
\hline Special transfer payments & 375 & 489 & 518 & 878 & 1360 & 1756 & 2355 & 2434 & 2577 & 3223 \\
\hline
\end{tabular}

Source: Calculations using "Finance Yearbook of China” from 1996 to 2005. Units = (100 million)

Note: sub-items do not add to category total because of exclusion of minor items. 
To recapitulate: the present transfer system consists mainly of the tax rebating program and earmarked grants. The general transfer payment that was intended to narrow the standardized fiscal gap between provinces accounts for only about a quarter of total transfers, though its relative importance has been growing since it was introduced in 1995. Taken as a whole, the present transfer system does not fulfill the fundamental purpose of reducing fiscal disparities while providing effective incentives to responsible local fiscal management. Future reforms should expand the size of the standardized transfer relative to tax rebating and earmarking.

\section{FISCAL DISPARITY IN CHINA}

In recent years, a big problem that has emerged is the increasing fiscal

disparity among regions. Regional inequalities have hindered harmonious economic development. Table 4 shows the situation in six provinces, ranging from the eastern coastal zone to the western areas of China. Fiscal disparities among the six areas have been continually growing. For example, in 2001, the wealthiest province (Shanghai) had per capita fiscal capacity of RMB 3776; the lowest (Guizhou) had only RMB 262.6. 1n 2003, the highest one (Shanghai) had fiscal capacity of RMB 5180 per capita, the lowest one (Guizhou) had 321.8. In other words, the fiscal disparity between the wealthiest and poorest province was more than 15 times. The overall fiscal disparity coefficient grew steadily between 1995 and 2003. Most of the economically developed and fiscally strong provinces are located in the eastern 
coastal area.

Table 4 Fiscal disparity among provinces (RMB/person)

\begin{tabular}{|c|c|c|c|c|c|c|c|c|c|}
\hline & 1995 & 1996 & 1997 & 1998 & 1999 & 2000 & 2001 & 2002 & 2003 \\
\hline guangdong & 525.90 & 659.50 & 748.20 & 881.40 & 1053.90 & 1252.50 & 1491.09 & 1528.97 & 1653.90 \\
\hline shanghai & 1489.60 & 1902. 80 & 2255.50 & 2582. 70 & 2849. 10 & 3292.90 & 3776.16 & 4362.78 & 5179.59 \\
\hline jiangxi & 148.40 & 182.20 & 209. 00 & 229.60 & 248.50 & 263.90 & 315.29 & 332.89 & 395.32 \\
\hline hunan & 165.60 & 199. 60 & 210.00 & 240.00 & 254. 90 & 271.00 & 311.42 & 348.69 & 403. 19 \\
\hline guizhou & 104.60 & 133. 30 & 150.60 & 176. 10 & 200.20 & 229.70 & 262.57 & 282.20 & 321.85 \\
\hline yunnan & 234.60 & 310.10 & 358.80 & 401.30 & 411.90 & 431.20 & 446.19 & 477.18 & 523.31 \\
\hline disparity & 1. 069 & 1. 104 & 1. 133 & 1. 134 & 1. 131 & 1. 153 & 1. 16 & 1.21 & 1.24 \\
\hline coefficient & & & & & & & & & \\
\hline
\end{tabular}

Source: China Statistical Yearbook from 1995 to 2004. The disparity coefficient is the standard deviation divided by the arithmetic mean.

The mismatch of governmental function and fiscal capacity among different levels

Another type of fiscal disparity is that between higher levels of government and lower tiers.

The reform of 1994 and its aftermath shifted fiscal revenues upward to the center. At 
the same time, higher levels, such as the central and the provincial governments, managed to shift expenditure responsibilities down to the basic levels, such as counties and townships. This has caused a mismatch between function and fiscal capacity at different levels.

In China, sub-provincial governments include city, county, and township governments. The sub-provincial fiscal situation outside of the big cities has become very difficult. The fiscal problems of basic levels of government have been exacerbated by the tendency of provincial governments to retain a high share of the revenues generated within the province. For example, the per capita fiscal revenue of Yunnan provincial government is 11 times greater than the per capita revenue of the county governments. Guangdong's per capita provincial revenue is 7 times greater than the counties'—despite the fact that much of the burden for service delivery and social welfare protection falls on the counties.

From a national perspective, the two highest levels of sub-national government (provincial governments and city or administrative regions) account for about $70 \%$ of all sub-national fiscal revenue, while the lower two levels (county and township) only have 30\%. Meanwhile, the sub-provincial transfer payment system still is not efficiently established. Because of this skewed fiscal revenue distribution, the fiscal capacity of the base levels of local government, outside the biggest cities, has worsened and worsened. 
Nowadays, the county and township governments undertake too many responsibilities. Some of these functions, such as compulsory education, militiaman training, social security, agricultural support, family planning, environmental protection, and poverty alleviation, should be assigned to higher-level level governments, especially the central government. Because of their excessive functional responsibilities, the basic levels of local government lack enough money to do the essential things that they should do.

\section{FISCAL MANAGEMENT AND LOCAL AUTONOMY}

Thus far, we have considered the fiscal flows resulting from tax-sharing and transfer arrangements. At least as important to the fiscal framework, and the impact on urban infrastructure finance, are the systems of intergovernmental hierarchy and the policies of central fiscal management.

\section{Limited Sub-National Autonomy}

At present, China maintains a multi-layer budget system, in which each level of government is responsible for its own budget. The People’s Congresses at each level are formally responsible for budgetary legislation and approval. Budgets are not submitted to higher-level governments for approval. Each level of government 
does, however report its budget and budget execution to the next level, and is responsible for conforming to budget rules.

In practice, the intergovernmental fiscal system is a blend of rules-based decentralization and hierarchical oversight that is a legacy of centralized planning. The Budget Law establishes fiscal limits for each tier of sub-national government. All sub-national governments are prohibited from having deficits, issuing bonds, or borrowing. Tax rates for all sub-national taxes are established at the central level; sub-national governments do not have the flexibility of modifying tax rates or introducing new forms of taxation.

A detailed reporting system is applied upward through the governmental hierarchy. The Economic Development and Reform Commission (formerly Planning Commission) at each level specifies in each five-year plan the physical development targets that the government will achieve, along with targets for local investment, economic growth rates and revenue collection. These targets reflect goals established at the national level and communicated downward to sub-national governments. Progress toward targets is closely monitored, both within the governmental system and within the parallel Communist party hierarchy. The political system abundantly rewards local leadership for achieving or exceeding goals, especially those referring to investment levels, physical development and economic growth reflected in fiscal revenue. 
Layered on top of this hierarchical structure and limited local autonomy is a countervailing tendency, distinctive to China, that is a legacy from the contracting period of decentralization (during the 1980s and 1990s up to the reforms started in 1994). This is the "off-budget fiscal fund" and a variety of other off-budget local resources. The off-budget thrust gained momentum during the period of contractual revenue sharing, when local and provincial governments had to share their budgetary revenues with higher levels of government according to contractual terms. Sub-national governments, especially those at the local level, responded by introducing a large number of special fees, special charges, and revenues realized from land leasing, which were not shared with, and often not reported to, higher-level governments. It is difficult to obtain exact information on the scale of these off-budget and other revenues, since one of the purposes behind the arrangement is to carve out revenue sources for which local authorities are not upwardly accountable. However, a special study of Beijing's revenue structure illustrates the scale of the problem.

Table 5: Structure of Beijing Municipal Revenue

\begin{tabular}{|c|c|c|c|}
\hline Year & 1998 & 1999 & 2000 \\
\hline On-Budget Revenue & $39.4 \%$ & $45.2 \%$ & $47.4 \%$ \\
\hline Formal “Off Budget” & $18.2 \%$ & $18.0 \%$ & $20.3 \%$ \\
Revenue & & & \\
\hline Other Revenue & $42.4 \%$ & $36.8 \%$ & $32.3 \%$ \\
\hline
\end{tabular}


Source: Cited in Zhang Rufei and Chreod Ltd., Shanghai Case Study, Report Prepared for Fiscal

Systems and Sub-National Growth Project, World Bank (2005)

The national government has sought to cut back the amount of non-reported revenues, first by greatly restricting the variety of fees that local governments can impose, on the grounds that many of the fees were "illegally" adopted and interfere with predictable business investment, and, secondly, by requiring local governments to report revenue from the list of authorized fees and some land leasing under a formal category of “off-budget revenue.” These initiatives have reduced the magnitude of unaccounted-for local revenue, but not eliminated it. Table 5 shows the modest progress being made toward reducing “other,” largely unreported revenue,

The question of budget organization and re-structuring is especially important to infrastructure financing, given that the largest part of financing has come from the proceeds of land leasing, fees, and asset income, which lie outside the regular local budget. The category, “fees”, is a composite of user-fees for services like water supply and a wide variety of more arbitrary fees imposed by local governments to generate revenue. At least until the most recent round of reforms, service-related user fees were a small part of the total. 


\section{From Pro-Active to Prudent Fiscal Policy}

Macroeconomic fiscal policy is established at the national level, under the guidance of the Ministry of Finance. An important shift in policy occurred in 2004, which has affected all parts of China's economy, but especially infrastructure finance.

After years of implementing a "proactive” fiscal policy—i.e., one of fiscal stimulus and economic development financed by borrowing-China in 2004 formally adopted a "prudent” fiscal policy—one of greater fiscal restraint with less reliance on borrowing. The pro-active policy was adopted largely in response to the Asian financial crisis, for the purpose of stimulating national growth. As the economy shook off the shadow of economic recession and entered into the rising phase of a new cycle, certain stresses became apparent in the latter half of 2003, such as overinvestment in some sectors like steel and inflationary pressures.

The content of the new "prudent” fiscal policy, announced at the National Peoples Congress, can be summarized as (i) controlling deficits and national borrowing, (ii) focusing fiscal resources on sectors that have critical bottlenecks or have lagged behind in the emphasis on general economic growth; these include agriculture, environmental protection and social protection of laid-off workers from State Owned Enterprises; (iii) devoting more attention to the fiscal impact on income 
distribution, including income differences between regions and between the rural and urban sectors; and (iv) reinforcing tax collection and budgetary management, in order to finance these initiatives within more nearly balanced budgets.

In terms of economic development strategy, this program has been called the "five balances"- that is, the need to balance urban and rural development, to balance the development of different geographical regions, to balance economic and social development, to balance the development of man and nature (environment), and to balance domestic development with international trade. One of the first steps in implementing “prudent” national fiscal policy was to lower the target for the 2005 central deficit.

\section{Identifying and Managing Fiscal Risk}

The move to “prudent” macroeconomic fiscal policy reflects the judgment that the greatest fiscal risk to China's sustained development now is public sector debt, as reflected both in the balance sheets of government, and in the balance sheets of banks and the financial sector. The national (central government) debt has grown to some RMB 2.1 trillion or about 60\% of GDP in 2005.

Non-performing loans threaten the domestic banking sector. The government already has relieved the banking sector of a large volume of non-performing loans, by 
forming special asset companies to assume these loans and the underlying assets.

Still, the government estimates that some 3.3 trillion of non-performing loans remain, and some outside analysts project that the share of non-performing loans is

considerably higher. A large part of the bad debt consists of loans to sub-national governments and to local State-Owned Enterprises.

There is no exact information on the aggregate volume of bad debt owed by sub-national governments. ${ }^{3}$ However, the total of direct non-performing loans, plus uncovered contingent liabilities, is likely to lie somewhere between RMB 800 billion and 1.2 trillion. This makes sub-national governments a very large part of the banking sector's aggregate debt problem. The issue of banks' bad debt takes on special urgency because of the WTO agreement allowing entry of foreign banks into domestic lending, which will bring well-financed new entrants into competition with China's domestic banks. In addition to offloading some of the banking sector's bad loans, the government has ordered banks to adopt much stricter lending standards for local governments and locally owned state owned enterprises.

Finally, under current intergovernmental expenditure responsibilities, sub-national governments will have to absorb a large part of the unfunded social

\footnotetext{
${ }^{3}$ Local governments technically are prohibited from borrowing. Borrowing is done on their behalf by special enterprises wholly owned by the local government, called Urban Development and Investment Companies (UDICs), which are the juridical holders of all local development assets and liabilities. However, these companies execute municipal government policy, report to the municipal government, and are owned by the municipal government. Banks typically require a municipal “comfort letter" backing UDIC loans. This states that the municipal government will do whatever it can to ensure that the UDIC is able repay its loans.
} 
security liability, which is estimated at some RMB 2.5 trillion. In all, public debt might account for more than $280 \%$ of GDP in 2005, threatening China’s future economic development if not handled prudently.

All of these factors point to the macroeconomic risk involved in increasing sub-national governments' debt by financing the large volume of urban infrastructure investment that is needed through borrowing. This is especially true if infrastructure investment is to be focused on laggard regions, and counties and townships, whose capacity to repay debt is limited. 


\section{PART II}

\section{IMPACT OF THE FISCAL FRAMEWORK ON URBAN INFRASTRUCTURE INVESTMENT}

Ever since the early 1990s, China’s urban public infrastructure has drawn great attention from all levels of governments. Investment has been climbing at a rapid rate. Total urban infrastructure investment during the "Eighth Five Year Plan" Period was RMB 260 billion, five times as much as in the "Seventh Five Year" Period, while during the "Ninth Five Year" Period, ending in 2000, the investment total grew to RMB 700 billion, 2.7 times the amount of the previous five years. The high rate of growth has continued through the Tenth Five-Year period.

China has a comprehensive physical reporting system, which makes it possible to track urban infrastructure capacity along various dimensions. Table 6 shows that the growth in most measures of urban infrastructure provision (and urbanization) has been remarkable. 
Table 6: Basic Statistics on Urban Infrastructure Coverage

\begin{tabular}{|l|l|l|l|l|l|}
\hline Item & 1990 & 1995 & 2000 & 2002 & 2003 \\
\hline Developed areas (sq. km) & 12856 & 19264 & 22439 & 25973 & 28308 \\
\hline Population density of urban districts (person/sqkm) & 279 & 322 & 442 & 754 & 847 \\
\hline Total floor space of buildings (100 million sqm) & 39.8 & 57.3 & 76.6 & 131.8 & 140.9 \\
\hline Per capita water consumption for residential use (ton) & 67.9 & 71.3 & 95.5 & 77.8 & 77.1 \\
\hline Percentage of population with access to tap water (\%) & 48 & 58.7 & 63.9 & 77.9 & 86.2 \\
\hline Percentage of population with access to gas (\%) & 19.1 & 34.3 & 45.4 & 67.2 & 76.7 \\
\hline Area of paved roads per 1000 population (sqm) & 3.1 & 4.4 & 6.1 & 7.9 & 9.3 \\
\hline Length of sewer pipelines per capita (m) & 3.9 & 6.0 & 6.8 & -- & -- \\
\hline Density of sewer pipelines (km/sqkm) & 4.5 & 5.7 & 6.3 & 6.7 & 7.0 \\
\hline \% of Treated Sewerage & 14.9 & 20.0 & 34.2 & 36.5 & -- \\
\hline Number of public transportation vehicles per 100 & 2.2 & 3.6 & 5.3 & 6.7 & 7.7 \\
\hline population (unit) & 6727 & 10671 & 11818. & 13650 & 14857 \\
\hline Volume of garbage disposal (10000 tons) & 2.5 & 3.7 & 5.4 & 6.5 \\
\hline
\end{tabular}

Sources: China statistical yearbook 2004

Despite this growth, many Chinese experts and policy officials believe that urban infrastructure investment lags behind the rate appropriate to the country's growth in urbanization, industrialization, and income level, and that urban infrastructure investment will have to accelerate in the future. 
One key element in this argument is China's commitment to urbanization as the primary domestic growth strategy. Although China has the most cities with a population of at least 1 million of any country in the world (171 in 2002), it remains largely a rural nation. Moreover, as a report of the Research and Development Center of the State Council points out, China has industrialized to a far greater extent than it has urbanized, and has urbanized faster than it has invested in urban infrastructure. ${ }^{4}$ China's degree of urbanization today corresponds to that of England in 1950, the United States in 1911, and Japan in 1950. If the worldwide correspondence between industrialization and urbanization were to hold true in China, the country would now be $60 \%$ urbanized, instead of just over $40 \%$.

China's economic growth strategy rests on continued rapid urbanization to absorb surplus rural labor. As Chen Yuan, Governor of China Development Bank, has written:

Urbanization is the most important and enduring motive force in stimulating consumption and investment in China's domestic economy today; it is also the engine to simultaneously propel our economic and social development. ${ }^{5}$

\footnotetext{
${ }^{4}$ Xie Fuzhan, "Speeding Up City Infrastructure Development Should Have a Sense of Urgency," (2004), www.china.org.cn/chinese/OP-c/466537.htm

5 Chen Yuan, “Development Financing and China’s Urbanization” (2005), www.cdb.com.cn/english/NewsInfo.asp?NewsID=1174
} 
Rapid and even accelerating urbanization will require very high rates of urban infrastructure investment to accommodate cities' population growth while at the same time improving coverage and service standards.

By some measures, China’s rate of urban infrastructure investment to date has been less robust than it may first seem. The World Bank's World Development Report of 1994 found that infrastructure investment in developing countries tended to average about $50 \%$ of total government investment, $20 \%$ of total national investment, and about 4\% of GDP. "Urban” infrastructure investment-i.e. infrastructure investment serving the municipal level--averaged about 3 to $4 \%$ of urbanized GDP. Table 7 shows that urban infrastructure investment levels in China have been rising rapidly over time, but remained a relatively modest share of total national investment as of 2000 (note that the urban infrastructure investment ratios in the table are calculated relative to total national investment and total national GDP). The most successful cities have made much greater commitments to urban infrastructure investment. Over the Ninth Five-Year Plan period (ending in 2000), Shanghai devoted $12.5 \%$ of total investment to urban infrastructure and $5.9 \%$ of regional GDP. In Beijing, $13.7 \%$ of total investment went to urban infrastructure, which corresponded to $6.3 \%$ of regional GDP, more than triple the share from earlier years. 
Table 7: Urban Infrastructure Investment Ratios

\begin{tabular}{|l|l|l|}
\hline Year & Ratio to Total Fixed & Ratio to GDP \\
\hline 1980 & $1.2 \%$ & $0.2 \%$ \\
\hline 1985 & $2.5 \%$ & $0.7 \%$ \\
\hline 1990 & $2.7 \%$ & $0.7 \%$ \\
\hline 1995 & $4.0 \%$ & $1.4 \%$ \\
\hline 2000 & $5.8 \%$ & $2.1 \%$ \\
\hline
\end{tabular}

Source: Construction Industry Publication of China as reported in Fu Tao (2004)

Government experts have estimated that approximately 20 to 30 percent spent on urban infrastructure construction during the $10^{\text {th }}$ Five Year Plan period, ending in 2005, will be expended by local, provincial, and central governments directly from budget (fiscal) resources. The remainder will be financed by a combination of domestic loans, foreign and multilateral loans, revenue from asset earnings and asset sales, and various forms of market-based financing.

\section{THE FISCAL FRAMEWORK AND INFRASTRUCTURE FINANCING OPTIONS}

Perhaps the best way to examine the linkage between the national fiscal framework and national fiscal policy, on the one hand, and urban infrastructure 
financing, on the other, is to look individually at the three broad channels that are responsible for the bulk of urban infrastructure financing. These are: direct budget investment from fiscal resources, borrowing, and market-based financing.

\section{Direct Budget Expenditures}

Direct budget expenditures on urban infrastructure investment include spending at the central, provincial, and local level from fiscal resources. Because urban capital construction is a local (sub-provincial) responsibility, the vast majority of spending is done by local governments. Before 1990, the main funds for urban infrastructure construction came from the local urban maintenance and construction tax and from public utilities surcharges. Now, local infrastructure investment in principle can be financed from general resources in the local budget, although for budget presentation purposes revenue from the urban maintenance and construction tax typically is allocated to infrastructure investment.

As described in Part I, sub-provincial governments have been placed in a fiscal squeeze stemming from a downward shift of expenditure responsibilities, an inadequate intergovernmental tax-sharing and transfer system, and the tendency of provincial governments to hold onto revenues rather than return them to the local level. One result has been strong pressure on local governments' budgets, which in turn has diminished the share of local budgets available to finance capital 
construction.

These trends have led to a steady decline in the proportion of urban

infrastructure investment that is financed from direct budget spending or operating surplus. Figure 5 shows that the proportion of total urban infrastructure construction financed by budgetary funds decreased from $50 \%$ in 1991 to $29 \%$ in 2001 . The decline has continued thereafter, and is projected to continue into the future.

Figure 5: Share of Urban infrastructure investment financed from the budget

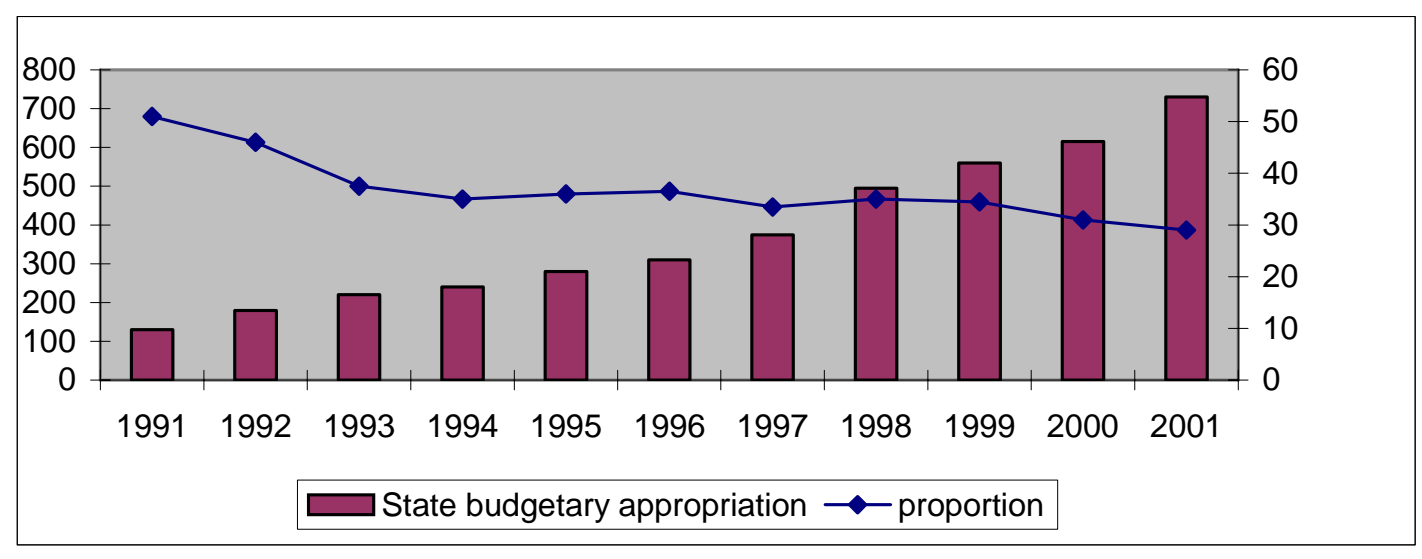

Source : Authors calculations

A second source of direct public financing is off-budget fees. As noted in Part I, central authorities have vigorously sought to rein in local fees, marked by periodic initiatives since 1994 (e.g., in 1996 and 2001) to limit the number of authorized fees to a restricted list and bring them within the formal revenue reporting system. Most of these fees did not take the form of service charges or user fees for service consumption (which have been increasing at central government urging), but 
were arbitrary fees levied on such items as construction permits and various “authorizations' for domestic and international business operations. Nonetheless, they provided a source of unrestricted local income that often was channeled into infrastructure investment. The growth of fees used for infrastructure finance up to the 1994 intergovernmental fiscal reform and the subsequent sharp fall-off is shown in Figure 6.

Figure 6: Share of Urban Infrastructure Investment financed by Fees and Charges

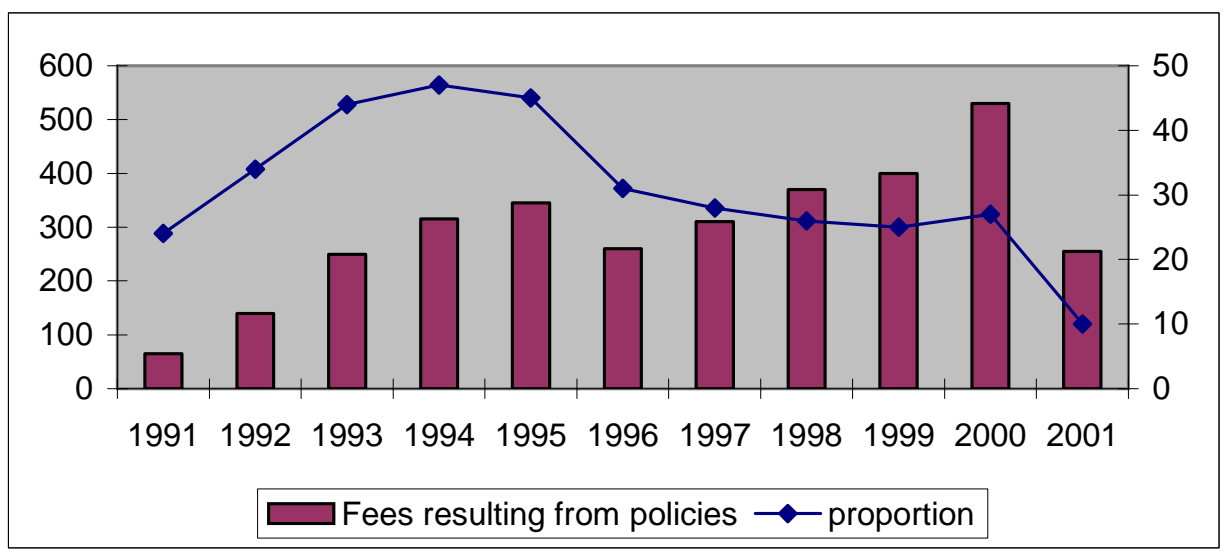

Source : Authors calculations

\section{Debt Financing}

The financing gap created by the decline in direct budgetary spending on urban infrastructure has been filled primarily by borrowing. In 1986, domestic bank lending for urban infrastructure totaled only RMB 0.32 billion accounting for $2.4 \%$ of total urban infrastructure investment. As Figure 7 makes clear, the share of investment financed by borrowing declined up to the 1994 fiscal reform, then began 
to explode. Although exact figures for post 2001 are not available, it is clear that borrowing volumes have continued to rise rapidly thereafter. By 2001, more than $60 \%$ of the cities in China had infrastructure loans from banks or outstanding loan applications. The total banking-sector debt of local governmental units for urban infrastructure stood at RMB 74.2 billion in 2001, up 23 fold in just a decade. Use of the banking sector to finance urban infrastructure investment was encouraged by national policy, which identified the urban infrastructure sector as a top priority for lending by banks, all of which were then owned by the State.

Figure 7: Share of Urban Infrastructure Investment Financed by Loans

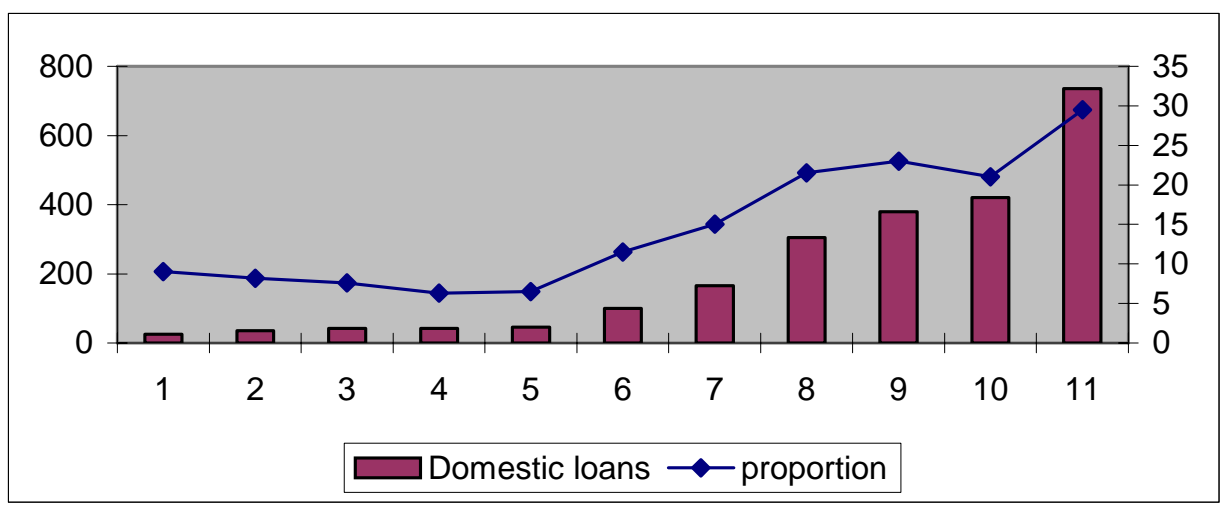

Source : Authors calculations

Central government borrowing and on-lending to local governments for infrastructure investment

Bank borrowing has not been the only the type of debt financing. The national government also issued so-called infrastructure bonds, and passed on the 
proceeds to provincial and local governments, as a blend of on-lending and grants. From 1998 to 2004, China issued long-term construction national debt of RMB 910 billion, of which RMB131.7 billion (roughly US\$16 billion) ${ }^{6}$ was for urban infrastructure financing. The money was used to build almost 2000 projects, including sewage and garbage disposal, water supply, and gas and heating in 28 provinces. Funds were steered toward poorer regions, especially those in the Western development area, and toward projects, especially those involving environmental protection, that could not recover costs through service charges or attract investment financing from the market.

Under the newly announced “prudent” fiscal policy, national government will substantially reduce debt issuance for urban infrastructure investment purposes. In fact, funds from national debt are now supposed to be used only to complete construction in progress, and not to finance new projects. This change in national policy will severely affect the financing capacity of many local governments, especially those in the underdeveloped provinces of western China, where market-based financing is difficult to mobilize.

\section{Structural Problems with Debt Financing}

The risks created by debt financing go beyond the sheer volume of sub-national debt. The bulk of bank loans have been provided by commercial banks.

\footnotetext{
${ }^{6}$ Exchange Rate used is $1 \$=\mathrm{RMB} 8.23$
} 
Although the maturity period of commercial bank loans for local infrastructure investment has gradually been extended, typical loans still do not exceed five to eight years. Even economically remunerative infrastructure investment projects cannot recover costs over such a short period, so local government must roll over their loans rather than repay them. From local governments’ perspective, rolling over shorter term infrastructure loans was a more viable proposition when local commercial bank branches were closely tied politically to local governments, and the entire banking system had planning targets for urban infrastructure investment to fulfill. Now, as part of financial de-regulation, the Peoples Bank of China no longer establishes sectoral lending plans for banks. Banks have been required to heighten credit standards and prodded to clean up non-performing loans. Local governments’ political control over local loans has been somewhat weakened in the effort to strengthen banks' balance sheets. Thus, the risk to local governments that old loans cannot be rolled over, and that debt financing for new projects cannot be obtained, is greater than before. From the banking side, the fact that local government loans were routinely rolled over, rather than required to be re-paid, has hidden the true degree of non-performing loans, which is now coming to light.

China Development Bank (CDB), as a long-term policy bank, stands out against this sectoral backdrop. CDB regularly makes urban infrastructure loans of 15-20 years, or even longer, and has been a leader in identifying new types of revenue streams that can enhance local creditworthiness. 
Central government on-lending for infrastructure investment from nationally issued bonds has been subjected to a variety of abuses, which the Ministry of Finance recognized in deciding to cut back the program. Local and provincial governments often obtained financing on the premise that it would be used to invest in environmental projects and other social projects unable to generate a full economic return, then would switch to economic development projects once the financing was in hand. Public tendering was circumvented. Provinces (and the local governments that received funds from them) would obtain funds as "loans," then plead inability to repay and succeed in getting re-payment waived. ${ }^{7}$

In part because of the legacy of state planning and state-directed financing of plans, the distinction between "loans" that must be repaid, and grants or transfers that are not to be repaid, has not been fully established at the sub-national level.

Provincial and local governments, especially in laggard regions, continue to treat loan repayment to the central government as a matter of political negotiation rather than commercial obligation. This injects an element of endemic risk into sub-national debt that central authorities now are trying to eliminate.

Fear of the inability to control sub-national debt risk also has made the central

\footnotetext{
7 See Fu Tao, “Local Credit Systems for Urban Environmental Infrastructure in China,” paper prepared for OECD (2004) and Wang, YX, Fang, Z., Ji, M, Huang, JL and Tan L , "A Study on the Multi-Channel Investment in China: Urban Environmental Infrastructure Construction in China,” Paper for Proceeding of the First Task Force Meeting for "Financial Mechanisms for Environmental Protection,” China Council for International Cooperation on Environment and Development (Nov. 2003)
} 
government unwilling to allow rule-based issuance of municipal bonds. All proposed local bonds must be individually approved, both by the next higher level of government and by the State Development and Reform Commission. Most such proposals are denied, or simply not acted upon. Local governments with strong economic bases, such as Shanghai, have sought bond approvals for years, but have been approved only intermittently.

\section{Marketization}

"Marketization" is the term used in China for mobilizing capital from the private or social sector to invest in urban infrastructure. National planning calls for generating larger shares of financing from this mode to replace the declining share of direct fiscal investment and in recognition of the prudential constraints on borrowing.

In the first generation of “marketization”, emphasis was placed on land leasing - i.e., the sale to private developers of land development and leasing rights owned by local government. Leasing rights, though good for a specified time period (typically 50 years in the case of commercial property), are sold up-front as a cash transaction. Proceeds from land leasing have been used primarily to finance infrastructure construction. In some cities, land sales have been able to finance more than $100 \%$ of all infrastructure investment, year in and year out, over a period of many years. In fact, during the last decade and a half, land leasing has been the 
principal source of urban infrastructure investment finance in larger cities. However, its importance has declined of late in those cities that were the first to enter the market, because of the decline in the supply of remaining land available for lease.

“Marketization” strategy is now moving toward a greater focus on infrastructure assets. This may take the form of selling existing assets (like water treatment plants and bridges) to the private sector for specific periods of ownership, but more significantly involves attracting private capital to finance new construction of assets. A July 2004 policy pronouncement by the central government State Council, “Decision on Investment and Organizational Reform,” formally reiterated the policy of approving social (private) capital investment in infrastructure and public utilities, and endorsed specific measures that would be necessary for implementing this broad policy, such as moving toward tariff rates that include an adequate return to capital and coverage of debt service, providing preferential tax treatment for private investment in urban infrastructure, and giving private investors in network systems (like wastewater collection and treatment) preferential rights to use network capacity for their own industrial and commercial projects.

Public policy in the short run has been motivated by a straightforward desire to mobilize financing for urban infrastructure investment. However, the marketization movement has opened up a broader discussion of how the urban infrastructure sector should be organized and how infrastructure services should be 
paid for.

\section{Role of Urban Development and Investment Companies}

According to public goods theory, the government should explicitly classify infrastructure into three different categories: infrastructure that can be operated profitably, quasi-profitable infrastructure, and infrastructure that is inherently non-profitable because of its public goods nature. Moreover, the scope of profitable infrastructure-i.e., infrastructure that can be operated on a profitable basis through service charges or other financial means—should be expanded as the market economy grows and as consumer ability to pay increases. For non-profitable infrastructure, government will remain the main financing body and investor. However, for profitable and quasi-profitable infrastructure, business enterprises should become the main builders and operators. Profitable infrastructure can stand on its own with appropriate service pricing; quasi-profitable infrastructure will need targeted government subsidies to become competitive.

The present urban infrastructure management system in China runs together these three infrastructure categories. Profitable infrastructure is combined with non-profitable infrastructure under the management of a single, monopoly State-Owned Enterprise, without clear guidelines differentiating the way the different types of infrastructure will be operated or financed. Each city has an Urban 
Development and Investment Company (UDIC, or City Development and Construction Company, as it is sometimes translated), whose function is to (i) mobilize financing for new infrastructure construction of all kinds, (ii) carry out construction of new infrastructure, and (iii) oversee the operation of existing infrastructure assets, running the gamut from mass transit systems to wastewater treatment plants, and water supply to trash collection and disposal.

This monopoly company is the juridical person that acts on behalf of the government to borrow funds from banks and other sources, issue bonds when allowed to do so, raise capital from Trusts and other special purpose vehicles, enter into joint ventures with private companies for infrastructure development, sell local infrastructure assets, assemble land packages for sale and development, serve as the implementing body for international loan programs, and oversee actual service delivery from the assets it owns, typically drawing upon complex cross-subsidization arrangements to keep all of its activities afloat.

UDICs were established in most cities at the end of the 1990s or even later, in response to a central government directive that responsibility for asset and liability management should be taken away from municipal governments and placed in the hands of specialized local enterprises. However, further unbundling is required. Potentially profitable and quasi-profitable infrastructure functions can be operated on a standalone basis that allows competition from private suppliers and can attract 
private capital for new ventures. UDICs will continue to have responsibility for the overall physical development of the city, and the financing and infrastructure strategies that are necessary to accomplish planning objectives. However, in changing from the plan-oriented economy to the market-oriented economy, a fundamental requirement is to eliminate the UDICs' monopoly over all phases of infrastructure development and operation and all types of infrastructure. UDIC’s job, in addition to overall infrastructure development strategy, should be to operate and upgrade those infrastructure services that are inherently unprofitable because of their public goods nature, while spinning off profitable and quasi-profitable infrastructure to other institutions that can participate in market-based competition.

Some UDICs have begun the unbundling process. The Shanghai Municipal UDIC, for example, has spun off a separate institution to invest in development of water and wastewater assets and negotiate agreements with private investors for new projects in the sector. Additional unbundling is in process. ${ }^{8}$

\section{Infrastructure Revenue Streams}

Whether capital funds are mobilized in the form of direct private investment or market-based loans, the economics of infrastructure investment is based on the

\footnotetext{
8 See Gao Guo Fu, "Urban Infrastructure Investment and Financing” Paper presented at the Practitioners' Conference on Mobilizing Urban Infrastructure Finance in a Fiscally Responsible Framework: Lessons from Brazil, China, India, Poland and South Africa” January 2005. http://www.worldbank.org/uifconference/
} 
revenue streams that are generated. Over the past 15 years, the most prolific and dependable revenue streams have been those attached to land. Special requirements or incentives for land developers to invest in associated off-site infrastructure have been another important source of infrastructure investment. The economic value of urban land is widely recognized in China, and the conversion of land-leasing rights or land development rights into infrastructure finance is widely practiced.

It has proved more difficult to implement market-based reforms of infrastructure service tariffs, like water tariffs, wastewater treatment charges, and garbage collection and disposal fees. The State Development and Reform Commission in October 2002 issued a circular on urban tariffs, stating that "cities with existing wastewater and garbage treatment facilities shall start to immediately charge a treatment tariff,” and that all other cities should do so before the end of 2003. Cities that had water, trash collection, wastewater treatment, and trash disposal tariffs were given a strict timetable for moving to tariff schedules that "shall cover operations cost and a reasonable investment return.” The purpose of the circular was specifically to make these urban infrastructure sectors attractive to private capital, so that investors could earn a satisfactory profit and lenders could have an adequate margin for payment of debt service.

In practice, almost all cities have failed to adopt full cost-recovery pricing for these basic services. Even the national government has backtracked. In 2004, it 
issued another circular prohibiting cities from raising service fees, as an inflation-fighting measure. Political reluctance to increase basic service fees has caused cities to look to private developers and larger commercial activities for alternative revenue streams that could be capitalized into investment financing. In its effort to clean up the Suzhou River, for example, the Shanghai Municipal Government granted project implementing agencies the right to collect a special drainage assessment charge from those who discharged into the river, creating a revenue stream that served as collateral for a large loan from the China Development Bank. 


\section{PART III}

\section{CONCLUSION: A POLICY AGENDA FOR THE FUTURE}

In looking to the future, it will be necessary to establish a more supportive fiscal framework for urban infrastructure investment that serves both economically strong and weaker local governments. The basic elements of such a reform package are:

The first is to better match expenditure responsibilities and fiscal ability. Along with development of the market-oriented economy, the marketability of urban infrastructure investment has been enhanced greatly, but local governments cannot withdraw from the infrastructure construction domain completely. They require fiscal resources commensurate with their expenditure obligations. In China the vertical fiscal imbalance has not been resolved. Fiscal revenues are centralized upward, so that outside of the biggest cities fiscal resources for infrastructure construction at the local level are extremely limited. Addressing this problem will require enlarging the scope of general transfers aimed at narrowing differentials in fiscal capacity, supplemented by special subsidies to meet specified standards for city infrastructure construction.

Even before implementing new fiscal transfers, however, it is imperative to 
more precisely distinguish each level of government's responsibilities in infrastructure provision and finance. At present, weaker local governments are being asked to handle more functions than they possibly can manage from existing resources.

Second, local governments’ fiscal autonomy should gradually be strengthened. Legislative power over local taxes now rests with the central government. The power to establish tax rates, and modify the local tax and fee structure, should be gradually released downward to local governments, within centrally determined limits, so that they can generate their own revenues according to the local development level and the local development strategy. This policy will primarily benefit rapidly growing cities with strong economic bases.

Third, the national Budget Law should be modified to allow local governments (or the Urban Development Investment Companies acting on their behalf) to raise financing from the capital market through bond issuance. At present, the intergovernmental systems of budget surveillance and control are inadequate to permit generalized access to a municipal bond market. However, certain cities whose economies, fiscal revenues, and management experience are stronger (such as Beijing and Shanghai) should be allowed to issue bonds for city construction, subject to general rules rather than case-by-case approval, as an experiment that, if successful, could be broadened to other cities. 
Fourth, the rules for converting land assets into infrastructure finance should be standardized. For the last decade and a half, land leasing has been the principal source of urban infrastructure financing in China’s big cities. However, municipalities’ manipulation of land markets has led to important development distortions, as municipalities began to act like profit-maximizing land monopolists. The national government must continue to clarify the rules for land acquisition and land disposition by municipal authorities.

Finally the framework for mobilizing capital from the social or private sector needs to be solidified. The present level of marketability in China has made it possible for private capital to access the city infrastructure domain. However, if private capital is to play the expansive role projected for it in the future, service tariffs for infrastructure must be increased to include capital costs and revenue streams must become fully reliable. Special incentives, like tax breaks for infrastructure investment, can help at the margin, but private investment on the scale envisioned will require that a significant portion of the urban infrastructure "industry" be placed on a routinely profitable basis, supported by service charges. 


\section{REFERENCES}

China Statistics Yearbook, 1994 to 2003, China Statistics Press.

Ming Su and Quanhou zhao, China’s Fiscal Decentralization, International

Symposium on Fiscal Decentralization in Asia Revisited, February 20-212004

Hitotsbashi Memorial Hall, Hitotsubashi University

China's inter-governmental fiscal relationship, edited by the budget department, MOF,

P. R. China, China Fiscal and Economic Press, April, 2003.

Study on establishing financing platform for urban infrastructure, by China investment academy, No.157, 2004-2005 report;

The research on the innovation of financing mechanism for urbanization, by China investment academy, No.164, 2004-2005 report;

Zhang Rufei and Chreod Ltd.. 2005 Shanghai Case Study, Report Prepared for Fiscal Systems and Sub-National Growth Project, World Bank

Xie Fuzhan, “Speeding Up City Infrastructure Development Should Have a Sense of Urgency,” (2004), www.china.org.cn/chinese/OP-c/466537.htm 
Chen Yuan, “Development Financing and China’s Urbanization” (2005), $\underline{\text { www.cdb.com.cn/english/NewsInfo.asp?NewsID }=1174}$

Fu Tao, “Local Credit Systems for Urban Environmental Infrastructure in China,” paper prepared for OECD (2004)

Wang, YX, Fang, Z., Ji, M, Huang, JL and Tan L , “A Study on the Multi-Channel Investment in China: Urban Environmental Infrastructure Construction in China,”

Proceeding of the First Task Force Meeting for "Financial Mechanisms for Environmental Protection,” China Council for International Cooperation on Environment and Development (Nov. 2003)

\section{ACRONYMS}

CDB China Development Bank

RMB Renminbi (Chinese local currency a.k.a Yuan)

SOE State-Owned Enterprises

UDIC Urban Development and Investment Company or City Development and Construction Company (as it is sometimes translated into)

VAT Value Added Tax

WTO World Trade Organization 